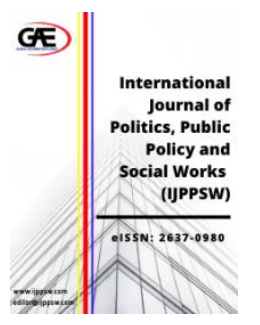

INTERNATIONAL JOURNAL OF
POLITICS, PUBLICS POLICY
AND SOCIAL WORKS
(IJPPSW)
www.ijppsw.com

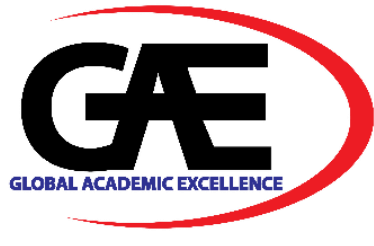

\title{
ATTRIBUTES OF STUDENT LEADERS IN IIUM TOWARDS VOTING
}

\author{
Faiswal Kasirye ${ }^{1 *}$, Saodah Wok ${ }^{2}$ \\ 1 Department of Communication, International Islamic University Malaysia \\ Email: kasirye.faiswal@gmail.com \\ 2 Department of Communication, International Islamic University Malaysia \\ Email:wsaodah@iium.edu.my \\ Corresponding Author
}

\section{Article Info: \\ Article history: \\ Received date: 27.09 .2020 \\ Revised date: 27.10 .2020 \\ Accepted date: 01.11.2020 \\ Published date: 02.12.2020 \\ To cite this document:}

Kasirye. F., \& Wok, S. (2020). Attributes of Student Leaders in IIUM towards Voting. International Journal of Politics, Publics Policy and Social Works, 2 (7), 24-49.

DOI: $10.35631 /$ IJPPSW.27003.

This work is licensed under $\underline{\mathrm{CC} B Y}$ B.0

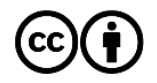

\begin{abstract}
:
Leadership is an essential aspect that people and communities worldwide depend on to make important decisions. The core function of leaders is to aid and support their followers to accomplish a common goal. The International Islamic University of Malaysia (IIUM) has been voting student leaders since its inception. These student leaders help in the administration of student affairs in several aspects. This study aims to examine the attributes of IIUM student leaders towards voting. Specifically, it aims to determine the relationships of qualities, characteristics, important ideal qualities of student leaders, and Islamic principles of leaders with voting in IIUM. The study utilizes the great man's theory of leadership to explain the relationships between the variables. The quantitative research design and survey method with a questionnaire as the tool for data collection were used in this research. A total of 327 IIUM students participated in this study. The findings of the study reveal that students look at their leaders in a positive and motivating way. They view the leaders as consistently performing an excellent leadership job and have good values through different characteristics, with important qualities and Islamic leadership principles. Additionally, students tend to consider both inbuilt and external attributes while voting for their leaders to be in power. The findings also show the presence of significant relationships among the variables of the study. The great man's theory is also supported in this study.
\end{abstract}

\section{Keywords:}

Attributes of Student Leaders, Islamic Attributes, Leadership, The Great Man's Theory, Voting 


\section{Introduction}

Over the years, leadership has been defined from several perspectives (Chemers, 2014). Every field has its own way of defining who a leader is, what functions he/she performs, what qualities he/she possesses, and how leadership is developed. Psychology, as a field, deals with leadership as a process of social influence in which one person can solicit the aid and support of others in his/her success (Chemers, 2014). This definition considers leadership as a process and the leader is the one that has influence. The important function of leadership here is to aid and support the leader's followers towards accomplishing a common task.

A university is a training ground for future leaders. In higher education institutions, attainment of leadership skills is one of the basic skills required in human capital development, and it is emphasized for undergraduate and postgraduate students alike (Shakir, 2009). It is a common practice among universities to incorporate student leadership training as part of the learning outcomes that are expected of graduates from their university education. Besides, leadership development and training is directly associated with the academic curriculum. Further, student societies and clubs are formed in the campus setting to provide leadership opportunities for students to learn and practice their leadership skills as part of their extra-curricular activities. By the time students graduate from a program, they are expected to have mastered not only technical knowledge and skills but also soft skills pertaining to leadership.

Student leadership in most learning institutions is a different area in research and practice, as education is a moral enterprise (Harris, 2013; Tan et al., 2015, 2018; Tie, 2018). However, the emerging trends in the last 15 years show a renewed focus on developing leadership outcomes in students, with the recent push largely due to the increased accountability for learning (Tie, 2018).

These emerging trends call for institutional and societal mandates that require learning institutions such as universities, colleges, and secondary schools to develop responsible student leaders (Tan et al., 2015, 2018). Besides, many questions have been raised concerning the leadership styles of student leaders to enable them to lead their respective organizations successfully. There is growing recognition that student leadership development is a responsibility of all members of the learning community and not just limited to those teaching leadership courses or those working with co-curricular leadership programs, as well as the inalienable attributes in the student leaders themselves (Tan et al., 2015, 2018).

Learning experience, coupled with the environment in higher education, has a great impact on a student's self-development. The purpose of higher education is not only to prepare students for entry into the workforce but also to produce individuals who can retain excellent skills and appropriate graduate attributes. Thus, the development of a well-rounded student learning experience should remain a central focus of universities (Mydin \& Rahman, 2018; Selamat et al., 2013). This can be achieved by creating a positive learning environment that helps students manage and develop their talents as well as building a good personality. In this context, providing students an environment that offers them opportunities for intellectual development, while also actively promoting the benefits of their involvement in wider co-curriculum activities is crucial.

\section{Problem Statement}

A number of studies have concentrated on student leaders rather than students themselves who put the leaders into such positions, and $85 \%$ of them look at questions that favor student leaders Copyright $\odot$ GLOBAL ACADEMIC EXCELLENCE (M) SDN BHD - All rights reserved 


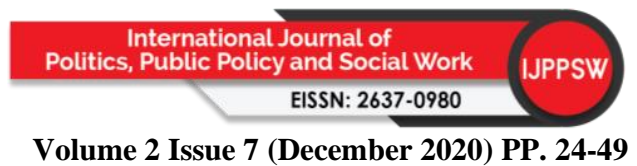

Volume 2 Issue 7 (December 2020) PP. 24-49

DOI: 10.35631/IJPPSW.27003

in different contexts and rarely focus on the students who vote the leaders into those positions (Harper \& Quaye, 2007; Harris, 2013; Tan et al., 2015).

A few studies have examined the attributes and experiences of students as influences on leadership. While past experiences including leadership activities would affect the behavior of student leaders, little information has been provided regarding the types of experiences and which might be more important. In addition, campus influences and their possible effect on leadership behavior have not been explored.

Growing up, children are not only kids but are also looked at as future leaders (Williams \& Johnson, 2013). The qualities, characteristics, and skills invested in them tend to determine their life and society's success (Williams \& Johnson, 2013). Additionally, student leadership is about focusing on communication, teamwork, planning, decision making, problem solving, and other skills. Raising the leaders of tomorrow means that embedding the skills in them. Leadership must be fostered in children from a very young age (Godbole, 2011; Nair, 2011). Indeed, if leadership qualities and skills are instilled in children from an early age, it will aid them in having strong personalities while growing up (Godbole, 2011). They are always expected to hold themselves in high esteem and also to act as an example to young aspiring leaders that will come after them. Therefore, this phenomenon has prompted this study to highlight the attributes, perception of important qualities of student leaders, and the Islamic perspective of leadership at International Islamic University Malaysia (IIUM).

The main questions though remain: Why are some students elected as student leaders? Do they have any special qualities? Could their qualities have been developed over time so that every student can become a leader? Is there any way to measure their leadership qualities and characteristics? This study hence focuses on understanding the attributes of IIUM student leaders towards voting.

\section{Research Objectives}

The main objective of this research is to examine the attributes of student leaders among IIUM students.

The specific objectives are:

1. To understand the level of leadership qualities among IIUM students;

2. To find out the attributes of Islamic leadership in IIUM student leaders;

3. To determine students' perception of the important qualities of an ideal student leader in IIUM;

4. To understand the level of participation of IIUM students in politics; and

5. To examine the relationship qualities of student leaders, characteristics of student leaders, Islamic leadership principle, perceived importance of ideal qualities of leadership and voting of IIUM student leaders.

\section{Significance of the Study}

In line with the above, the findings of this study are expected to contribute to a greater body of knowledge in creating and supporting an all-inclusive, engaging student experience through the underlying framework of the great man's theory of leadership. The theory has been used in similar studies but not in the context of learning institutions like IIUM. As will be highlighted in the literature review section, several studies have been carried out on student leadership and their qualities at primary and secondary school levels and they are quite general rather than specific. Moreover, minimal research has been done on the subject of attributes of student Copyright (C) GLOBAL ACADEMIC EXCELLENCE (M) SDN BHD - All rights reserved 


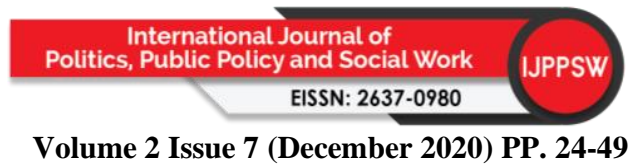

Volume 2 Issue 7 (December 2020) PP. 24-49

DOI: 10.35631/IJPPSW.27003

leaders, specifically in the context of IIUM. Therefore, this paper attempts to fill the gaps in research on the attributes of student leaders in a higher learning institution like IIUM.

This study hopes to further provide insights into areas in which leadership qualities can be enhanced to help emerging leaders be better prepared to lead in the future. IIUM student leaders will in fact benefit more as this study is focused on them.

Data gained from this study are expected to provide useful information to student affairs practitioners. As Godbole (2011) suggested, the relationship between student government and student affairs officers is critical. Therefore, the data from this study could enhance the communication between students and their leaders and assist those leaders in developing programs while they are in office.

As for practical contributions, the findings of this study are expected to serve as a guiding tool for policy formulation and implementation by the government and its agencies as far as the conduct of governance of learning institutions and student bodies is concerned, in formulating policies on student leadership, with a view of improving the leaders' roles in line with fulfilling students' expectations.

The findings from this research are also expected to contribute to the existing scholarly knowledge in this domain and will be eminent, specifically for IIUM, where little has been done about the attributes of student leaders.

\section{Literature Review}

\section{Qualities of Student Leaders}

A leader is someone who can use interpersonal skills to influence the attitudes, beliefs, feelings, and behavior of others. They lead and guide the performance of a group (Pierce \& Newstrom, 2006). Earlier research has been done to explore the characteristics that can help differentiate effective leaders from ineffective leaders (Tan et al., 2015). An analysis of the relationship between individual qualities and the effectiveness of leadership shows that there is a link between individual differences and leadership effectiveness (Hoffman, Woehr, MaldagenYoungjohn, \& Lyons, 2011).

Hay and Dempster (2016) showed that student leadership is a multifaceted job that involves interrelated skills and qualities. In addition, they point to a number of student leader qualities such as proper planning, reflection, problem solving, team building, decision making, goal setting, time management, project management, resource allocation, effective communication networking, conflict resolution, diversity awareness, and self-confidence, among others.

It is believed that a successful and efficient leader has some physical and psychological qualities that differentiate them from non-leaders (Manning \& Curtis, 2017). Previous studies have shown that students are aware of the importance of leadership as they perceive leadership experience as important on campus and even after college, as indicated by a student survey on attitude about student leadership (Shertzer, Wall, Frandsen, Guo, Whalen, \& Shelley, 2015).

Leadership is a necessary quality or skill for everyone. However, this skill cannot be learned only via formal education or by telling students about the importance of leadership and teamwork. These lessons are read and forgotten easily. Hence, leadership becomes part of Copyright (C) GLOBAL ACADEMIC EXCELLENCE (M) SDN BHD - All rights reserved 


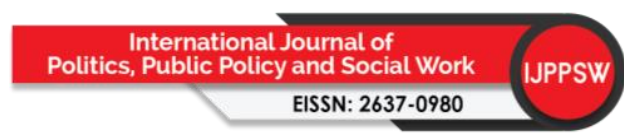

Volume 2 Issue 7 (December 2020) PP. 24-49

DOI: 10.35631/IJPPSW.27003

students if they read about it or someone talks about it in front of them (Shinde, 2010). It ought to be inborn or inalienable in them. Additionally, one easy way to teach students leadership is to organize co-curricular activities regularly. Literature related to student leadership provides parents and teachers with many activities to inculcate leadership qualities and skills, which will teach students not only the importance of leadership but also new leadership skills while promoting existing ones (Charlie, 2011; Kessie, 2012; National FFA Organization, 2009; Shinde, 2010).

Voyer (2011) states that effective leaders should be courageous. According to Tracy (2012), courage means that leaders are willing to take risks to achieve their goals with no assurance of success. Among the basic leadership qualities, courage is the most identifiable outward attribute. Courage is the act of possessing the strength of character to persist and to hold on to ideas in the face of opposition (Bedford, 2012; Voyer, 2011). It is not restricting as it relates to fear. Besides, if leaders want to see more courageous action by teams, they should consider whether they are modeling some of the traits of courageous leaders, such as seeking feedback and listening, encouraging push back, and communicating frequently (Tardanico, 2013).

Different studies throughout history have identified different leadership qualities that leaders possess (Hoffman et al., 2011 and Manning et al., 2007). The common leadership qualities are self-confidence, adjustment, sociability, integrity, persistence, initiative, responsibility, and insight (Pierce \& Newstrom, 2006).

Therefore, the qualities of student leaders can be seen as those that adhere to being confident, courageous, tolerant, fair, accountable, God-fearing, helpful, and good in communication skills. Further, student leaders should have teamwork and be presentable at the same time, as well as being able to help other students in need. They should also respect the views of fellow students, be the timekeepers, and be very keen and practical in motivating others in addition to knowing how to make fair decisions as leaders.

\section{Characteristics of Student Leaders}

The development of leaders and the building of leadership capacity among students through co-curricular activities have become a common feature at universities world over (Foreman \& Retallick, 2016). According to Larson, Wilson, and Mortimer (2012), students are potential future leaders and universities are seen as the perfect training ground to prepare them with the knowledge and skills necessary for later use at the workplace and in society. Leadership skills learned and practiced through experiential learning activities, leadership courses, conferences, academic courses, associations, and student organizations help them build their own character strengths in addition to their inalienable characteristics that are inbuilt in them by default.

At IIUM, student leaders possess certain life characteristics and experiences that influence their leadership, effectiveness of leadership, and duties as student leaders. Such experiences have enabled them to develop skills and characteristics that are positive and beneficial in present and future leadership endeavours. Students also have the opportunity to observe other individuals in leadership situations and will copy their positive behaviours. At the same time, through experience and observation, students can recognize and avoid negative behaviours and characteristics that can affect leadership. All behaviours, both positive and negative, provide benefit and learning which in the long run can guide student leaders and assist them in leadership activities in and around the university. 


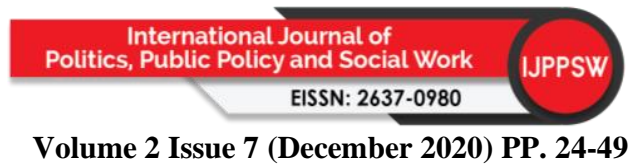

Volume 2 Issue 7 (December 2020) PP. 24-49

DOI: 10.35631/IJPPSW.27003

Additionally, for a team to be productive and successful, members and leaders need to be able to identify, address, and resolve conflicts successfully. Like any other leadership skill, conflict management can be learned (Trautman, 2017). According to Moore (2010), conflict resolution is problem solving by sitting down and discussing each other's points of view without fighting or arguing. The basic skills needed for conflict resolution are listening, communication, selfdiscipline, critical thinking, creative thinking, and personal responsibility, all of which are characteristics that a great leader should possess. Without such skills, students are not able to resolve problems in their lives or with other people with whom they live and study. When a conflict is mismanaged, it can cause great harm to a relationship, but when handled in a respectful, positive way, it provides an opportunity to strengthen the bond between two people (Segal \& Smith, 2013).

Being strategic and visionary are probably the most important characteristics of a student leader (Chobharkar, 2011). Considering all dimensions of problems as well as their future consequences and solutions is what a student leader needs to do. According to the author, being visionary will demand many skills such as decision making, planning, having the ability to give influential pep talks, motivation, and sharing leadership.

In the present study, vision is looked at as one of the many characteristics essential for a student leader. Thus, when leaders are campaigning for their elections, they always highlight and sell their vision to the electorates (students), who are the sole beneficiaries of the outcome of every action. The supporters are supposed to acknowledge the vision and understand it and, in most cases, base it in voting for their desired candidates.

The other trait of leadership that corresponds with student leaders is decision making. They are involved in making decisions on a routine basis because they are leaders that represent students on different platforms in and out of the university. This involves identifying the pros and cons of making a choice, evaluating the evidence, getting closure, and selecting one option (FosterFishman et al., 2017).

Allowing students to make decisions for them is therefore very important. They may start with small decisions, and later adults like their parents, teachers, and leaders can allow them to make bigger decisions as they begin to understand the concept of responsibility and consequences. In addition, students can model good decision-making skills in their everyday life. While this is important, student leaders should not forget to talk to fellow students about why they make the choices they do, and how consequences shape the decisions they make (Bedford, 2012; Hay \& Dempster, 2014; Swan, 2011). Therefore, student leaders can be characterized as decision makers, wise, problem solvers, honest, intelligent, good speakers, confident, disciplined, communicators, visionary, and likable. Student leaders should also be able to make hard decisions in uncertain situations, convince other students to participate in university activities once called upon, and help others to find solutions by giving them proper knowledge and counselling. Besides, they should be friendly and kind in addition to helping others in their academic endeavour and motivating them in other non-academic fields.

\section{Islamic Principles on Leadership}

Leadership in Islam is similar to conventional leadership, except it has religious, moral, and human roots. The religious and moral spirit aspect dominated leadership during the reign of Prophet Muhammad (SAW) and the four caliphs (Al-Buraey, 2006). Islamic leadership exists 


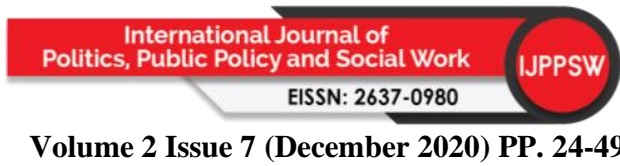

Volume 2 Issue 7 (December 2020) PP. 24-49

DOI: 10.35631/IJPPSW.27003

in both the Qur'an and Sunnah, which are the primary sources of guidance, in addition to the practices of early Muslim scholars.

In Islam, leadership serves as a bridge that is used by leaders to influence their followers' attitudes and behavior to achieve certain objectives (Ali, 2007). It is the ability to see beyond the boundaries to come up with solutions that only a few can visualize. A leader must be a visionary to lead an organization to success (Khaliq, 2009).

Leadership in Islam is a process of inspiring and coaching voluntary followers to achieve a clear and defined vision (Adnan, 2006). More so, it is seen as human factors that bind a group together and motivate it towards the desired goal. Hence, a leader is not free to act as they choose, nor must they submit to the wishes of any group, but they should act only to implement Allah's laws on earth. For this, Allah says:

"And We made them leaders guiding men by Our command and We sent inspiration to do good deeds, to establish regular prayers, and to practice regular charity; and they constantly served Us only" (Al-Anbiya' [21]: 73).

The Islamic leadership principles compiled by Muslim authors are endless. For example, in a study by Khan (1998), some of the Islamic leadership principles practiced by the Prophet (SAW) were recognized as seeing an advantage in a disadvantage, changing the place of action, making a friend out of an enemy, turning a minus into a plus, looking at the power of peace as stronger than that of violence, not to be a dichotomous thinker, bringing the battle in one's own favorable field, gradualism instead of radicalism, and to be realistic in controversial matters and many others. Additionally, the Prophet (SAW) was a positive thinker and his activities were always result-oriented by completely refraining from all such steps that may prove unproductive.

Khaliq (2007a, b) similarly wrote on some leadership qualities that were exhibited by the Prophet (SAW). These qualities include patience, eloquence, enterprise, and leniency. Ismail (2007) emphasized two principles that were regularly practiced by the Prophet (SAW), namely, (1) receiving the message, which is a principle equated to the act of seeking guidance and knowledge in order to direct the affairs to the followers and (2) spreading the message, referring to the act of delegating tasks and ensuring that they are well accomplished.

Khan (2007) indicated some Islamic leadership principles, including faith and belief, knowledge and wisdom, courage and determination, mutual consultation and unity, morality and piety, honesty and trust, superior communication, justice and compassion, patience and endurance, commitment and sacrifice, lifelong endeavor, and gratitude and prayers.

Religion is a foundation where leadership is the guardian of everything that does not have a foundation and would therefore collapse if not guided well (al-Ghazali: 1994). His opinion appears as the formulation of the complementary relationship between Islam and leadership.

Islam gives a leader the obligation to be fair. Justice becomes a vibrant part for the leader because a leader creates justice. Therefore, fair leaders get guaranteed protection from Allah in the hereafter (Hadith Bukhari, no. 572). More explicit, the duties of a leader can be seen from the Hadith of the Prophet (SAW) narrated from Umar ibn al-Khattab:

“... O my Lord! Indeed, I ask you to bear witness to the leaders in all over the country. Indeed, I sent them to be fair to people, teach people the science of religion, the Sunnah 


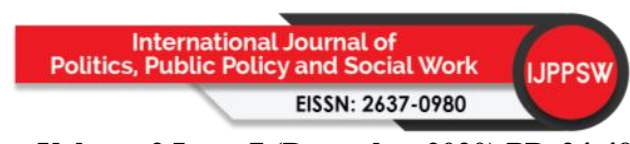

Volume 2 Issue 7 (December 2020) PP. 24-49

DOI: 10.35631/IJPPSW.27003

of the Prophet, distribute among them the spoils with honest and resolve any problems that they find difficult "(Hadith Bukhari, no. 316).

Morally, leaders are supposed to embrace the principles mentioned above because during the application of those principles, they not only get appreciation from the people they lead but rather also receive blessings from Allah for fulfilling their duties to their followers.

Islamic attributes that define student leaders in this study include humanity, determination, patience, trust, vision, responsibility, accountability, knowledgeable, forgiving, honesty, Godfearing, respectful, trustworthy, and self-sacrifice. Islam also encourages student leaders and leaders in general to be sincere in what they do, humble, compassionate, reliable, and fair in their actions and decision making. The principles above help define a Muslim leader and he/she should embrace these principles to earn respect and to be rewarded by The Almighty.

\section{Student Participation in Voting}

Institutions of higher learning like IIUM have an immense responsibility in grooming future leaders with strong characters (Skalicky et al., 2018). Students' involvement in various political activities across university campuses has a tremendous impact on their leadership skills (Foreman \& Retallick, 2016; Stephens \& Beatty, 2015). Student governance, for example, is specifically designed to develop leadership capabilities among students. Apart from significant growth in leadership skills, political activities have a great impact on a student's civic responsibility, multicultural awareness, personal and societal values as well as voting (Cress, Astin, Zimmerman-Oster, \& Burkhardt, 2016). According to Beatty (2015), there are four types of participation, namely voting, participating in campaign activities, contacting public officials, and participating in cooperative or communal activities.

Students who are involved in governance automatically position themselves as the ones with responsibility over others, especially because they are voted into office. This is in tandem with the definition of a student leader by Cress et al. (2016) who describes a student leader as "one who for example, devotes considerable energy to studying, spends a lot of time on campus, participates actively in student organizations and interacts frequently with faculty members and other students" (p. 297).

Students' voting of a government in power therefore provides a valuable platform for students to develop core values through a variety of programs and political activities that they organize. Skills and competencies used in the process of organizing and managing these political activities are considered part of experiential learning (Layfield et al., 2000). Furthermore, Cress et al. (2016) reiterates that skills of teamwork, communication, and problem solving are somehow developed through well-designed learning environments.

In the past, students on university campuses confirmed their involvement in political activities such as leading, voting, student representation, and advocacy (Hay and Dempster, 2016). Voting presented opportunities for increased involvement in university affairs as well as developing skills that benefited their career endeavors because in the process, they participated in leadership activities after they were voted in office. Formal positions in government enable students to become involved in institutional governance and refine their leadership skills. This type of politics also presents an opportunity that allows students to become involved in the university community and make contributions and gain skills which can be beneficial now and in the future. The importance of this political experience must be noted in the context of its 


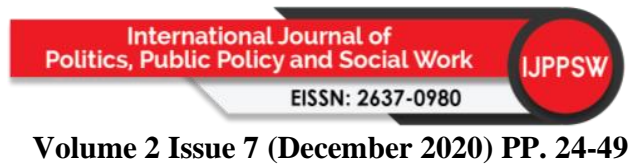

Volume 2 Issue 7 (December 2020) PP. 24-49

DOI: 10.35631/IJPPSW.27003

effect on the community. Hay and Dempster (2016) recognized the potential of student leadership on a college campus, noting that "a student government should be an important community-building institution" (p. 7).

Students' involvement in university governance is a manifestation of the democratic process where students can actively contribute to the management of their university through voting their leaders into office (Lizzio \& Wilson, 2009). It is an example of how the university displays its objective of producing leaders at the university level.

Elections in general influence students' decisions on who they should and should not vote as their leaders. They also stress on the issue of becoming interested in leadership issues once they vote. This translates to that voting their leaders opens a vital role and path in their lives.

\section{The Great Person Theory of Leadership}

The historian Thomas Carlyle introduced this great theory during the $19^{\text {th }}$ century. Earlier, leadership was considered as a quality associated mostly with males, and therefore the theory was named the great man theory. The term "Great Man" at the time or leadership was thought of primarily as a male quality, especially in terms of military leadership (Cherry, 2012). However, later, with the emergence of many great women leaders, the theory became known as the great person theory. According to Carlyle, a leader is one that is gifted with unique qualities that capture the imagination of the masses. The theory assumes that the capacity for leadership is inherent and that great leaders are born rather than made. This and other leadership theories often portray great leaders as heroic, mythic, and are destined to rise to leadership when needed (Cherry, 2012).

Great leaders are simply born with the necessary internal characteristics such as charisma, confidence, intelligence, and social skills that make them natural-born leaders. The theory implies that those in power deserve to be there because of their special talents. Furthermore, the theory contends that these characters remain stable over time and across different groups. Thus, it suggests that all great leaders share these characteristics regardless of when and where they live or the precise role in history they fulfilled.

The theory further suggests that one either has the qualities or does not have them. Leadership qualities are carried in the genes. In other words, they are inborn or inherent in the family from generation to generation. Such examples of great leaders are drawn from people like Prophet Muhammad (SAW), Mahatma Gandhi, Martin Luther King, Mao Tse Tung, Abraham Lincoln, George Bush, and many others. They were born natural leaders with built-in qualities of leadership and attained greatness by divine design.

They were not trained in leadership, nor did they acquire any leadership skills anywhere in their lives. Such skills were natural to them (Cherry, 2012). In other words, there was something in their structure, composition, and personality, which marked them out from common people. They had an instinctive urge to assume leadership and an inborn will to achieve greatness and success. People turned to them automatically for inspiration, solace, and support.

The implications of the theory indicate that leaders are God's gift to mankind. A measure of divinity is attributed to leaders and their actions. Not everyone can aspire to become a leader 
Volume 2 Issue 7 (December 2020) PP. 24-49 DOI: 10.35631/IJPPSW.27003

and attain greatness. Inherent leadership qualities alone are necessary and sufficient for a leader to exercise influence over their followers and become successful.

This paper suggests that there is a relationship between the qualities of student leaders, characteristics of student leaders, Islamic leadership principles, perceived importance of ideal qualities of leadership, and voting. In order to test this, the relationships between the independent variables, namely, qualities of student leaders, characteristics of student leaders, Islamic leadership principles, perceived importance of ideal qualities of leadership and voting as the dependent variable are depicted in Figure 1 and hypotheses are developed for the study.

\section{Summary of Hypotheses}

Based on the literature review and the conceptual framework of the study, the following hypotheses are conceived:

H1: There is a positive relationship between the qualities of student leaders and voting among IIUM students.

H2: There is a positive relationship between the characteristics of student leaders and voting among IIUM students.

H3: There is a positive relationship between Islamic leadership principles and voting among IIUM students.

H4: There is a positive relationship between the perceived importance of qualities of an ideal student leader and voting among IIUM students.

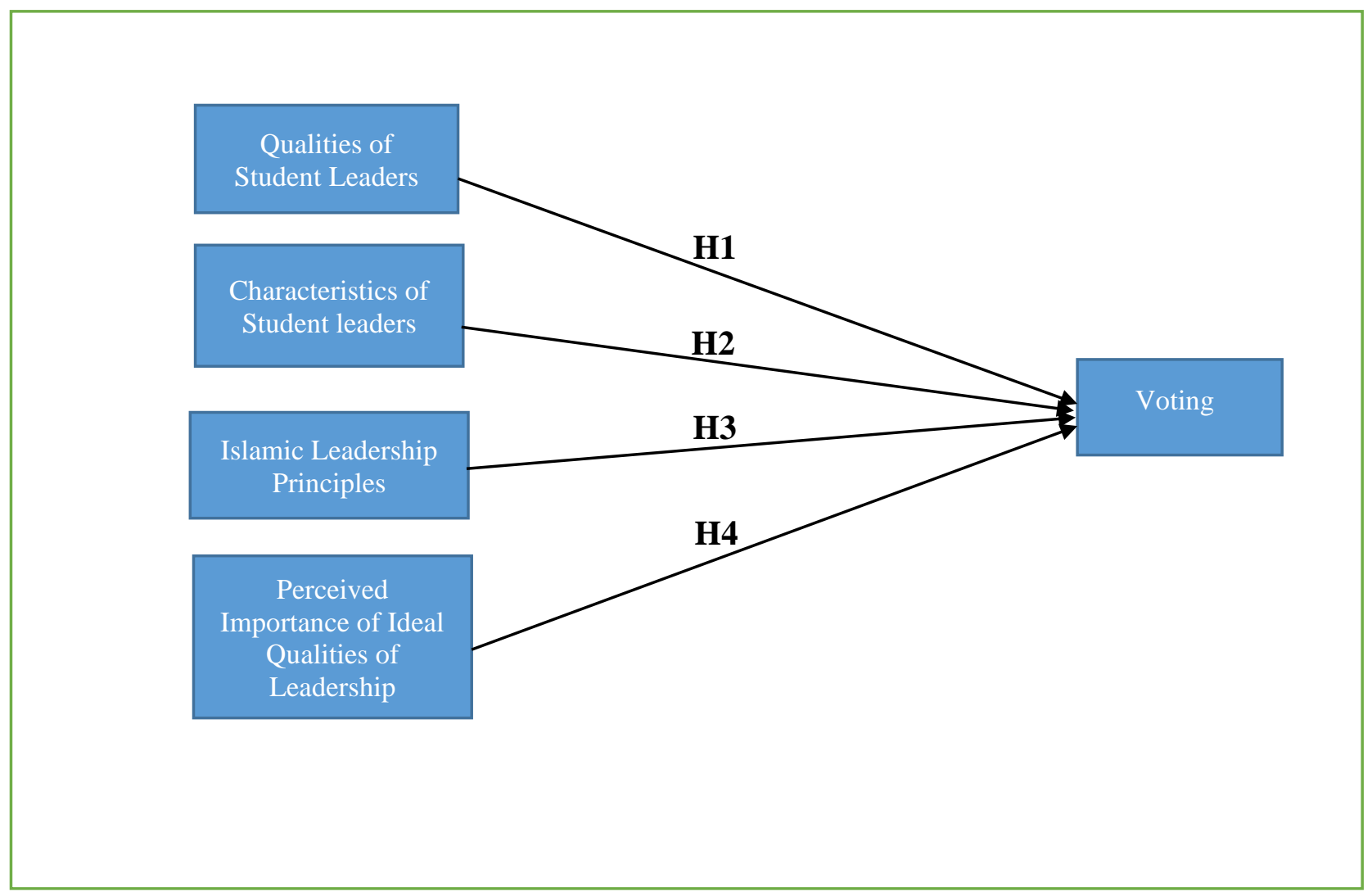

Figure 1: Conceptual Framework for The Attributes of Student Leaders in IIUM Towards Voting 


\section{Research Methodology}

\section{Research Design}

The study employed a quantitative research design and used the survey method, which is suitable for collecting large sets of data within a short time. Data were gathered using a selfadministered questionnaire and an online survey in Google Form. This method allows for sufficient data gathering on the target population of students from diverse demographic backgrounds such as age, gender, nationality, level of education, year of study, and their Kulliyyah.

\section{Population and Sampling Procedure}

Responses were gathered from IIUM students at the Gombak campus as the target population for this study. These students were chosen under the assumption that the study is about student leaders and students to whom they belong, thereby making the students qualified to answer any questions related to their student leaders. Additionally, the study was conducted during a period when the students were electing their new leaders into office, therefore making it timely.

A total sample size of 327 was obtained through probability random sampling, where the population has an equal chance of being randomly selected to participate in the study. This type of sampling increases the level of reliability of the findings, and it also has the best chance to create a sample that is truly representative of the population (Saunders et al., 2007). Consent was sought and gained from the respondents before they filled out the survey forms.

\section{Data collection and Instrumentation}

The instrument used for data collection in this study is a survey questionnaire with two selfadministered methods, namely, (1) a face-to-face self-administered questionnaire and (2) an online survey using Google Forms, after which 327 responses were computed for analysis. Data from both the face-to-face questionnaire and online survey were collected at the IIUM main campus in Gombak during a two-week period from March 29 until April 12, 2020. A self-administered questionnaire ensures that respondents are free from the pressure of impressing the researcher. Questionnaires also help to save the researcher's time and cost. Besides, they are adaptable and can minimize bias (Creswell, 2014).

The questionnaire consisted of six sections. Section 1 featured general data on the demographics of the respondents, whereas sections 2 to 6 were adapted from different scholars. Section 2, which focused on the qualities of IIUM student leaders (16 items), was adapted from Weir (2014). Section 3 featured the perception of important qualities of ideal student leaders (16 items) and Section 4 assessed the characteristics of student leaders (29 items); these sections were adapted from Shah and Pathak (2015). Section 5 measured the Islamic leadership principles (23 items) and was adapted from Rafiki (2020). Lastly, Section 6, which featured students' voting (13 items), was taken from Pontes, Henn, and Griffiths (2018). Sections 2, 3, 4 , and 5 were treated as the independent variables of the study, whereas Section 6 was treated as the dependent variable.

The multiple questions in this study were measured on a 5-point Likert scale ranging from 1 to 5 for sections 2, 3, 4, and 5. Sections 2, 4, and 5 had a scale from strongly disagree to strongly agree, where $1=$ strongly disagree, $2=$ disagree, $3=$ slightly agree, $4=$ agree, and $5=$ strongly agree. Meanwhile, section 3 had a scale from not important to very important, where $1=n o t$ important, $2=$ slightly important, $3=$ fairly important, $4=$ important, and $5=$ very important . 
Volume 2 Issue 7 (December 2020) PP. 24-49 DOI: 10.35631/IJPPSW.27003

Lastly, Section 6 was on a Likert-like scale of never to always, where $1=$ never, $2=$ rarely, 3 = sometimes, $4=$ often, and $5=$ always. To calculate the overall percentage of an item, the mean score for the item was multiplied by 20 , which is equivalent to $100 \%$ based on the 5point scale. Therefore, an overall percentage was acquired by multiplying the mean score by 100 and dividing it by 5 (Wok \& Hashim, 2014).

An example of items for the qualities of IIUM student leaders is "the student leaders fulfill their promises." The perception of important qualities of ideal student leaders includes the item of "competent," while the characteristics of student leaders include "is likable," and Islamic attributes of leadership encompass "humility." The voting items include "elections influence my decision on voting."

\section{Validity and Reliability}

A pilot study $(N=30)$ was conducted before the actual study to measure the flow of the statements and any other problems that might be faced by the respondents. The questionnaire was also reviewed and approved by an expert in the field of measurement. An internal reliability test was conducted using Cronbach's alpha. The data collected from the pilot study indicated that all items from the five variables were significant and exceeded the minimum Cronbach's alpha value of .70 to indicate the reliability of the variables. Table 1 shows the results that confirm the internal cohesiveness and consistency of the variables for the pilot study with Cronbach's alpha values ranging from .742 to .930. For the actual study, the Cronbach's alpha values obtained are: qualities of IIUM student leaders $(\alpha=.882)$, perception of important qualities of ideal student leaders $(\alpha=.868)$, characteristics of student leaders (.907), Islamic leadership attributes $(\alpha=.877)$, and voting $(\alpha=.842)$. Therefore, all variables were very reliable.

Table 1: Means, Standard Deviations, and Reliability of Selected Variables in the Study

\begin{tabular}{clccc}
\hline Section & \multicolumn{1}{c}{ Variables $(\boldsymbol{N}=\mathbf{3 2 7})$} & $\begin{array}{c}\text { No. of } \\
\text { items }\end{array}$ & \multicolumn{2}{c}{ Reliability (Cronbach's $\boldsymbol{\alpha})$} \\
\hline & & & $\begin{array}{c}\text { Pilot study } \\
(\boldsymbol{N}=\mathbf{3 0})\end{array}$ & $\begin{array}{c}\text { Actual study } \\
(\boldsymbol{N}=\mathbf{3 2 7})\end{array}$ \\
2 & Qualities of IIUM student leaders & 16 & .742 & .882 \\
3 & Perception of important qualities of & 16 & .811 & .868 \\
4 & ideal student leaders & 29 & .930 & .907 \\
5 & Characteristics of student leaders & 23 & .758 & .877 \\
6 & Islamic leadership attributes & 13 & .803 & .842 \\
\hline
\end{tabular}

\section{Data Analysis}

Data from the study were compiled and analyzed using Statistical Package for the Social Sciences (SPSS) Version 23. Then, descriptive and inferential statistical analyses were carried out. The descriptive analysis includes frequencies, percentages, means, and standard deviations, while the inferential analysis includes one-sample $t$-tests for testing the level of the variables. Bivariate correlations were used to test the relationships between the dependent variable and independent variables. 


\section{Results and Discussion}

\section{Demographic Characteristics of the Respondents}

The study comprised 327 valid responses from the target population. Table 2 shows the detailed results of the demographic characteristics of the respondents. Half the number of respondents $(51.7 \%)$ was female while the rest of them $(48.3 \%)$ were male students. In terms of their age, more than two-thirds of the respondents $(68.2 \%)$ fall in the $21-25$ years old age group, $22.9 \%$ are below 20 years of age, and the rest $(8.9 \%)$ are 26 years old and older. On their education level, almost half of the respondents $(44.7 \%)$ were pursuing their bachelor's degree while the rest were either doing their postgraduate $(31.2 \%)$ or foundation $(24.2 \%)$ program. There was a considerable number of Malaysian students (70.9\%) compared to international students $(29.1 \%)$. In terms of their level of study, approximately a third of the respondents were secondyear students $(30.3 \%), 27.8 \%$ were in their first year, while third- and fourth-year students made up $20.2 \%$ and $21.7 \%$ of the respondents, respectively. Additionally, the majority of the respondents $(82.9 \%)$ were registered voters in their respective countries while the rest $(17.1 \%)$ had not registered. Also, almost all the respondents (93.3\%) had voted at least once, whereas $6.7 \%$ had never participated in any type of voting exercise.

Overall, almost all the respondents are registered as voters and had participated in a voting exercise at least once. This finding is in line with the permissible age for voting of 18 years old, and most of them have fulfilled that criterion.

Table 2: Demographic Characteristics of the Respondents

\begin{tabular}{|c|c|c|c|}
\hline $\begin{array}{l}\text { Demographic } \\
\text { Characteristic }\end{array}$ & Category & Frequency & Percentage \\
\hline \multirow[t]{3}{*}{ Gender } & Female & 169 & 51.7 \\
\hline & Male & 158 & 48.3 \\
\hline & Total & 327 & 100.0 \\
\hline \multirow[t]{6}{*}{ Age (years old) } & Less than 20 & 75 & 22.9 \\
\hline & $21-25$ & 223 & 68.2 \\
\hline & $26-30$ & 22 & 6.7 \\
\hline & $31-35$ & 4 & 1.2 \\
\hline & $36-40$ & 3 & 0.9 \\
\hline & Total & 327 & 100.0 \\
\hline \multirow{4}{*}{ Level of education } & Foundation & 79 & 24.2 \\
\hline & Bachelor Degree & 146 & 44.7 \\
\hline & $\begin{array}{l}\text { Master's } \\
\text { Degree/PhD }\end{array}$ & 102 & 31.2 \\
\hline & Total & 327 & 100.0 \\
\hline \multirow[t]{3}{*}{ Nationality } & Malaysian & 232 & 70.9 \\
\hline & International & 95 & 29.1 \\
\hline & Total & 327 & 100.0 \\
\hline \multirow[t]{5}{*}{ Year of study } & First & 91 & 27.8 \\
\hline & Second & 99 & 30.3 \\
\hline & Third & 66 & 20.2 \\
\hline & Fourth & 71 & 21.7 \\
\hline & Total & 327 & 100.0 \\
\hline $\begin{array}{l}\text { A registered voter in your } \\
\text { country }\end{array}$ & Yes & 271 & 82.9 \\
\hline
\end{tabular}




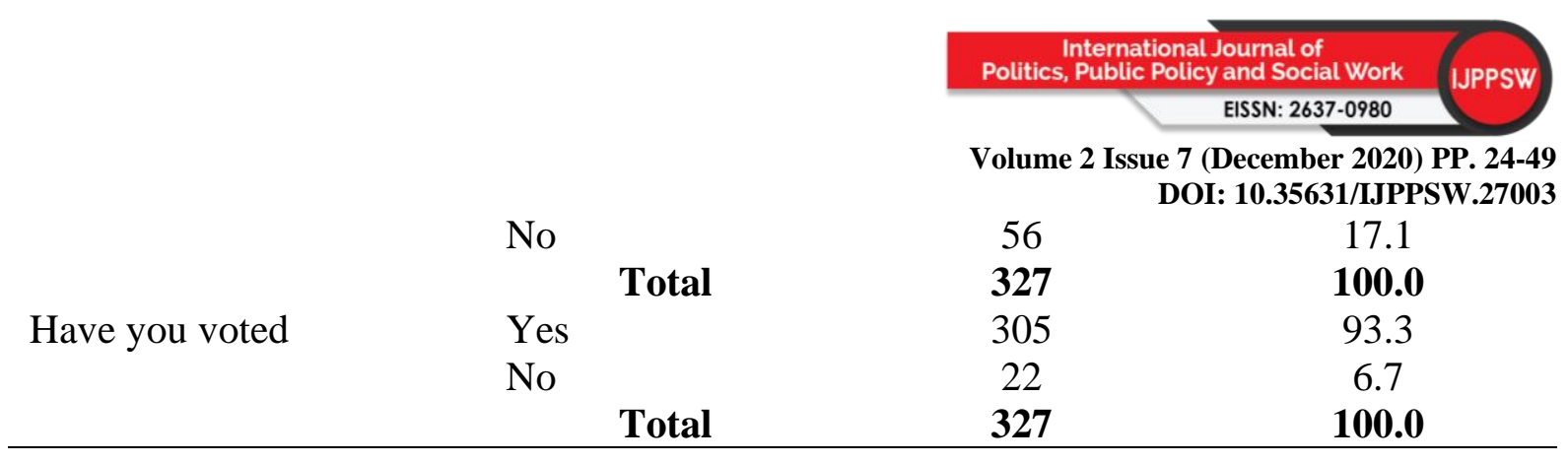

\section{The Level of Qualities of IIUM Student Leaders}

Table 3 shows the one-sample $t$-test results for the qualities of IIUM student leaders. Overall, two-thirds of the respondents $(68.0 \%)$ regarded the qualities of IIUM student leaders as high, with a mean of $3.404(S D=0.653)$ and $t$-value of $11.209(\rho=.000)$. Their convictions of the high qualities of IIUM student leaders is due to different reasons, namely, that the student leaders fulfill their promises $(76.6 \%)$; they are punctual during meetings $(74.1 \%)$; they listen well to their peers $(73.7 \%)$; and the student leaders are confident $(72.8 \%)$, consistent $(71.9 \%)$, and communicate well with others $(71.3 \%)$. In addition, the student leaders respect the views of their peers $(70.8 \%)$ and inspire them at the same time $(69.4 \%)$. Importantly, the student leaders are trustworthy $(68.3 \%)$, helpful to fellow students $(66.2 \%)$, presentable $(65.0 \%)$, and consistent $(63.7 \%)$ in what they do all the time. However, the same results also reveal that the student leaders hardly work as a team $(62.2 \%)$ and they rarely motivate their peers $(62.2 \%)$. Additionally, the respondents noted that the student leaders hardly make fair decisions $(61.0 \%)$ and they lack politeness (59.6\%). Overall, the findings indicate that most of the items were positively evaluated.

Table 3: One-sample $t$-Test for the qualities of IIUM Student Leaders

\begin{tabular}{|c|c|c|c|c|c|c|c|}
\hline No. & Leadership Qualities & $\mathbf{M}^{*}$ & SD & $\%$ & $t * *$ & $d f$ & $\rho$ \\
\hline 1 & The student leaders fulfill their promises. & 3.834 & 1.007 & 76.6 & 14.981 & 326 & .000 \\
\hline 2 & $\begin{array}{l}\text { The student leaders are punctual during } \\
\text { meetings. }\end{array}$ & 3.706 & 0.990 & 74.1 & 12.897 & 326 & .000 \\
\hline 3 & $\begin{array}{l}\text { The student leaders listen well to their } \\
\text { peers. }\end{array}$ & 3.688 & 1.099 & 73.7 & 11.315 & 326 & .000 \\
\hline 4 & The student leaders are confident. & 3.642 & 0.931 & 72.8 & 12.461 & 326 & .000 \\
\hline 5 & The student leaders are consistent. & 3.596 & 1.130 & 71.9 & 9.538 & 326 & .000 \\
\hline 6 & $\begin{array}{l}\text { The student leaders communicate well } \\
\text { with others }\end{array}$ & 3.565 & 1.068 & 71.3 & 9.573 & 326 & .000 \\
\hline 7 & $\begin{array}{l}\text { The student leaders respect the views of } \\
\text { their peers. }\end{array}$ & 3.541 & 1.098 & 70.8 & 8.913 & 326 & .000 \\
\hline 8 & The student leaders inspire their peers. & 3.474 & 1.115 & 69.4 & 7.6 & 326 & .000 \\
\hline 9 & The student leaders are trustworthy. & 3.415 & 1.166 & 68.3 & 6.448 & 326 & .000 \\
\hline 10 & $\begin{array}{l}\text { The student leaders are helpful to } \\
\text { students. }\end{array}$ & 3.311 & 1.169 & 66.2 & 4.821 & 326 & .000 \\
\hline 11 & The student leaders are presentable. & 3.253 & 1.166 & 65.0 & 3.933 & 326 & .000 \\
\hline 12 & The student leaders are consistent. & 3.189 & 1.151 & 63.7 & 2.978 & 326 & .000 \\
\hline 13 & The student leaders motivate their peers. & 3.113 & 1.216 & 62.2 & 1.681 & 326 & .094 \\
\hline 14 & The student leaders work as a team. & 3.110 & 1.213 & 62.2 & 1.641 & 326 & .094 \\
\hline 15 & The student leaders make fair decisions. & 3.052 & 1.270 & 61.0 & 0.740 & 326 & .460 \\
\hline 16 & The student leaders are polite. & 2.981 & 1.255 & 59.6 & -0.264 & 326 & .794 \\
\hline & Overall Leadership Qualities $(N=327)$ & 3.404 & 0.653 & 68.0 & 11.209 & 326 & .000 \\
\hline
\end{tabular}

* On a 5-point Likert scale, where $1=$ strongly disagree, $2=$ disagree, $3=$ slightly agree, $4=$ agree, and $5=$ strongly agree.

**Test value is 3

Copyright $\odot$ GLOBAL ACADEMIC EXCELLENCE (M) SDN BHD - All rights reserved 


\section{Level of Perception of Important Qualities of Ideal Student Leaders}

The one-sample $t$-test results for the respondents' level of perception of the important qualities of ideal student leaders are presented in Table 4 . The results demonstrate that, as a whole, the largest portion of the respondents $(73.4 \%)$ regarded highly on the important qualities of ideal student leaders $(t=21.386 ; \rho=.000)$ with a mean of $3.670(S D=0.566)$. The respondents perceived highly on some important qualities of their student leaders such as competent $(80.4 \%)$, respecting others $(80.3 \%)$, courageous $(78.2 \%)$, loyal $(76.8 \%)$, decision makers (73.7\%), wise (73.5\%), hardworking (72.9\%), helpful (72.9\%), problem solver (72.8\%), honest $(72.6 \%)$, intelligent $(72.3 \%)$, good speaker $(71.0 \%)$, visionary $(70.4 \%)$, confident $(70.1 \%)$, communicators (69.1), and maintain discipline (66.9\%). The results confirm that the levels of perception of the qualities of ideal student leaders are high. This means that the student leaders have important qualities of ideal leaders, which make them potential great leaders in the future.

Table 4: One-Sample $t$-Test for the Perception of Important Qualities of Ideal Student Leaders

\begin{tabular}{llcccccc}
\hline No. & \multicolumn{1}{c}{ Important Qualities } & $\mathbf{M}^{*}$ & SD & $\mathbf{\%}$ & $\boldsymbol{t}^{* *}$ & $\boldsymbol{d f}$ & $\boldsymbol{p}$ \\
\hline 1 & Competent & 4.021 & 0.947 & 80.4 & 19.488 & 326 & .000 \\
2 & Respect others & 4.015 & 1.049 & 80.3 & 17.497 & 326 & .000 \\
3 & Courageous & 3.914 & 0.895 & 78.2 & 18.458 & 326 & .000 \\
4 & Loyal & 3.841 & 1.008 & 76.8 & 15.076 & 326 & .000 \\
5 & Decision Maker & 3.685 & 1.003 & 73.7 & 12.339 & 326 & .000 \\
6 & Wise & 3.675 & 0.955 & 73.5 & 12.790 & 326 & .000 \\
7 & Hard working & 3.648 & 0.979 & 72.9 & 11.973 & 326 & .000 \\
8 & Helpful & 3.648 & 0.963 & 72.9 & 12.169 & 326 & .000 \\
9 & Problem solver & 3.642 & 0.954 & 72.8 & 12.164 & 326 & .000 \\
10 & Honest & 3.630 & 1.177 & 72.6 & 9.672 & 326 & .000 \\
11 & Intelligent & 3.617 & 1.029 & 72.3 & 10.855 & 326 & .000 \\
12 & Good speaker & 3.550 & 0.985 & 71.0 & 10.096 & 326 & .000 \\
13 & Visionary & 3.522 & 0.996 & 70.4 & 9.492 & 326 & .000 \\
14 & Confident & 3.507 & 1.171 & 70.1 & 7.833 & 326 & .000 \\
15 & Communicator & 3.458 & 1.106 & 69.1 & 7.496 & 326 & .000 \\
16 & Maintains discipline & 3.348 & 1.059 & 66.9 & 5.948 & 326 & .000 \\
& Overall Important Qualities $(\boldsymbol{N}=\mathbf{3 2 7})$ & $\mathbf{3 . 6 7 0}$ & $\mathbf{0 . 5 6 6}$ & $\mathbf{7 3 . 4}$ & $\mathbf{2 1 . 3 8 6}$ & $\mathbf{3 2 6}$ & $\mathbf{. 0 0 0}$ \\
\hline
\end{tabular}

* On a 5-point Likert scale where $1=$ not important, $2=$ slightly important, $3=$ fairly important, $4=$ important, and $5=$ very important .

$* *$ Test value is 3

Competence, respecting others, and being courageous are the three most important qualities considered by students to be an ideal student leader. These findings differ slightly from those of Weire (2014), who considered confidence as the utmost importance in student leadership quality. This difference is related to the different cultures between Western and Asian countries.

\section{Level of Characteristics of Student Leaders}

The levels of characteristics of student leaders are presented in Table 5. The respondents' views on the characteristics of student leaders are significantly positive $(69.8 \%)$ with an overall mean of $3.493(S D=0.622)$ and $t=14.353,(\rho=.000)$. The item with the highest mean is "likable" while the lowest mean is "IIUM student leaders are easy to work with" reflecting a negative and insignificant $t$ value of $-1.238(\rho=.217)$. Students also believed that their leaders can make 
informed decisions in uncertain situations $(76.0 \%)$, are polite while talking to people $(74.3 \%)$, try to improve themselves in every field $(74.0 \%)$, accept feedback $(72.8 \%)$, kind while talking to others $(72.6 \%)$, volunteer in helping with campus activities $(72.1 \%)$, treat their friends and other classmates equally (71.9\%), friendly (71.8\%), help others in academics (71.2\%) as well as possessing other positive characteristics. However, the same students also reported that the student leaders do not complete the required assignments on time (62.4\%) and they are difficult to work with $(58.1 \%)$. Hence, it can be concluded that student leaders have various characteristics that aid them in executing their duties while in office. The results indicate that IIUM students have a positive level of characteristics of being student leaders.

Table 5: One-Sample $t$-Test for the Characteristics of Student Leaders

\begin{tabular}{|c|c|c|c|c|c|c|c|}
\hline No. & $\begin{array}{c}\text { Leadership Characteristics of Student } \\
\text { Leaders }\end{array}$ & $\mathbf{M}^{*}$ & SD & $\%$ & $t^{* *}$ & $d f$ & $\rho$ \\
\hline 1 & Is likable. & 804 & 989 & 76.0 & 14.692 & 326 & .000 \\
\hline ? & $\begin{array}{l}\text { Can make decisions in any uncertain } \\
\text { situations. }\end{array}$ & 341 & 79 & 76.0 & 4.637 & 326 & .000 \\
\hline 3 & Is polite while talking to other people. & .718 & .943 & 74.3 & 13.776 & 326 & .000 \\
\hline 4 & . & 3.703 & 984 & 74.0 & 12.914 & 26 & .000 \\
\hline 5 & ack (advice/criticism). & & & 72.8 & & & .000 \\
\hline 6 & Is kin & & & 6 & & & .000 \\
\hline 7 & helping with campus & 0 & 0 & 2.4 & 8 & 6 & .000 \\
\hline 8 & friends and other classmates & 8 & 36 & 72.1 & 10.622 & 326 & .000 \\
\hline 9 & plans to complete designated & 3.596 & 1.037 & 71.9 & 10.397 & 326 & .000 \\
\hline 10 & $\begin{array}{l}\text { Is } \\
\text { un }\end{array}$ & 6 & 9 & 71.9 & 79 & 326 & .000 \\
\hline 11 & Is $\mathrm{fr}$ & 3.590 & 14 & 71.8 & 9.575 & 326 & .000 \\
\hline 12 & $\begin{array}{l}\mathrm{C} \\
\text { un }\end{array}$ & 3.565 & 4 & 71.3 & 9. & 326 & .000 \\
\hline 13 & $\begin{array}{l}\text { Hell } \\
\text { field }\end{array}$ & 3.562 & 966 & 71.2 & 10 & 326 & .000 \\
\hline 14 & & & & & & & .000 \\
\hline 15 & Is a & 8 & 5 & 70.7 & & 6 & .000 \\
\hline 16 & mistakes an & 3.538 & 1.070 & 70.7 & 9.096 & 326 & .000 \\
\hline 17 & $\begin{array}{l}\text { Sh } \\
\text { to }\end{array}$ & 3.504 & 099 & 70.0 & 0 & 326 & .000 \\
\hline 18 & ents to do well in & 3.437 & 1. & 68.7 & 7.854 & 326 & .000 \\
\hline 19 & $\mathrm{Pe}$ & & & & & 6 & .000 \\
\hline 20 & Is $\mathrm{p}$ & & & 68.4 & & 6 & .000 \\
\hline 21 & $\begin{array}{l}\text { Helps othe } \\
\text { proper kno }\end{array}$ & 3.406 & 1.086 & 68.1 & 6. & 326 & .000 \\
\hline 22 & $\begin{array}{l}\text { I can trust the decision taken by this } \\
\text { person. }\end{array}$ & & & 67.8 & & 326 & .000 \\
\hline 23 & es proper guidance to & & 1.074 & 67.0 & 5.917 & 326 & .000 \\
\hline
\end{tabular}


24 Strives to maintain excellence in performance.

25 Acts as a mediator between other students, teachers and higher university authority.

26 Networks and engages everyone around campus.

27 Provides other students in need with help.

28 Completes given work on time.

29 Easy to work with.

Overall Characteristics of Student Leaders $(N=327)$

$\begin{array}{llllll}3.336 & 1.069 & 66.7 & 5.687 & 326 & .000 \\ 3.305 & 1.207 & 66.1 & 4.579 & 326 & .000 \\ & & & & & \\ 3.305 & 1.104 & 66.1 & 5.009 & 326 & .000 \\ 3.287 & 1.046 & 65.7 & 4.968 & 326 & .000 \\ 3.122 & 1.247 & 62.4 & 1.774 & 326 & .077 \\ 2.908 & 1.339 & 58.1 & -1.238 & 326 & .217 \\ \mathbf{3 . 4 9 3} & \mathbf{0 . 6 2 2} & \mathbf{6 9 . 8} & \mathbf{1 4 . 3 5 3} & \mathbf{3 2 6} & \mathbf{. 0 0 0}\end{array}$

* On a 5-point Likert scale where $1=$ strongly disagree, $2=$ disagree, $3=$ slightly agree, $4=$ agree, and $5=$ strongly agree.

**Test value is 3 .

Among the characteristics, students perceived their student leaders as being likable, polite, and can make decisions in uncertain situations, along with being kind and accepting feedback from their followers. These findings are in agreement with Swan (2011), who indicated that it is important for students to make their own choices of leaders depending on what they see in them. Larson, Wilson, and Mortimer (2002) added that since students are potential future leaders and universities are seen as the perfect training ground to prepare them with the knowledge and skills necessary for later use in the workplace and society, such characteristics are important for students as well as student leaders themselves.

\section{Level of Islamic Leadership Attributes}

A one-sample $t$-test was performed to ascertain the level of Islamic leadership attributes. Table 6 indicates that on average, six in ten $(65.4 \%)$ respondents believed that their student leaders have a high level of Islamic leadership attributes $(t=8.498 ; \rho=.000)$ with a mean value of $3.272(S D=0.579)$. Respondents regarded their leaders as possessing Islamic attributes in their leadership in terms of humility $(81.7 \%)$, courage and determination $(72.6 \%)$, patience/endurance $(71.1 \%)$, trust $(71.0 \%)$, decision making $(70.6 \%)$, strategic thinking $(68.3 \%)$, visionary $(68.3 \%)$, exemplary $(67.2 \%)$, accountable $(67.0 \%)$, responsible $(67.0 \%)$, sincere $(65.6 \%)$, humble (65.2\%), knowledgeable (65.1\%), forgiving $(64.0 \%)$, honest $(64.0 \%)$, compassionate $(63.8 \%)$, and reliable $(63.5 \%)$. However, the results for student leaders' Godfearing, respectfulness, fairness, and trustworthiness are not significant. Meanwhile, selfsacrifice $(54.4 \%)$ and truthfulness $(51.3 \%)$ were found to be significantly low. The findings show that a few items were not positively evaluated, but the students still regarded their leaders highly in terms of other Islamic attributes.

Table 6: One-sample $t$-Test for Islamic Leadership Attributes

\begin{tabular}{llcccccc}
\hline No. & Islamic Leadership Attributes & $\mathbf{M}^{*}$ & SD & $\boldsymbol{\%}$ & $\boldsymbol{t} * *$ & $\boldsymbol{d} \boldsymbol{f}$ & $\rho$ \\
\hline 1 & Humility & 4.085 & 0.888 & 81.7 & 22.085 & 326 & .000 \\
2 & Courage determination & 3.633 & 1.047 & 72.6 & 10.924 & 326 & .000 \\
3 & Patient/endurance & 3.556 & 1.216 & 71.1 & 8.271 & 326 & .000 \\
4 & Trust & 3.550 & 0.976 & 71.0 & 10.193 & 326 & .000 \\
5 & Decision maker & 3.532 & 1.101 & 70.6 & 8.737 & 326 & .000 \\
6 & Strategic thinker & 3.419 & 1.139 & 68.3 & 6.646 & 326 & .000
\end{tabular}


Volume 2 Issue 7 (December 2020) PP. 24-49

DOI: $10.35631 /$ IJPPSW.27003

$7 \quad$ Visionary

8 Exemplary

9 Accountable

10 Responsible

11 Sincere

12 Humble

13 Knowledgeable

14 Forgiving

15 Honest

16 Compassion

17 Reliable

18 God fearing

19 Respectful

20 Fairness

21 Trustworthy

22 Self-sacrifice

23 Truthfulness

\subsection{9}

3.363

3.354

3.354

3.284

3.263

3.259

3.201

3.238

3.192

3.177

3.097

3.088

2.966

2.932

2.721

2.565
1.032

1.156

1.086

0.992

1.060

1.205

1.191

1.206

1.098

1.222

1.218

1.168

1.219

1.209

1.285

1.356

1.313
68.3

67.2

67.0

67.0

65.6

65.2

65.1

64.0

64.0

63.8

63.5

61.9

$61.7 \quad 1.316$

$\begin{array}{ll}59.3 & -0.503\end{array}$

$\begin{array}{ll}58.6 & -0.947\end{array}$

$\begin{array}{ll}58.6 & -3.710\end{array}$

$\begin{array}{ll}54.3 & -5.979\end{array}$

.000

Overall Islamic Attributes on Leadership $(N=327)$

\section{$\begin{array}{llllll}3.272 & 0.579 & 65.4 & 8.498 & 326 & .000\end{array}$}

\footnotetext{
* On a 5-point Likert scale where $1=$ strongly disagree, $2=$ disagree, $3=$ slightly agree, $4=$ agree, and $5=$ strongly agree.

**Test value is 3
}

For the present study, the respondents highlighted many characteristics such as humility, courage, patience, and trust as important attributes that they need to see in their student leaders. These findings support the results of Rafiki (2020) about Islamic leadership qualities and comparisons. Further, he exclaimed that the responsibility of leaders must follow the main principles or the usul al-din of Islam and not against it. In addition, from the comprehensive explanation of Islamic leadership concepts, leaders can be an idol, a reference, or a role model that gives a good impression to all followers. They lead their people based on a given trust; thus, they should not abuse their power. They realize that the power accorded to them is temporary and is to bring peace and preservation of the Islamic divine law (maslahah or usululfiqh) to society, and that they will have to hand it over to someone else after them. Islam also has some concerns about the power and authority of leaders. Both attributes must be used accordingly for the benefit of society.

\section{The Level of Voting Participation}

All the items on voting participation (exercise) demonstrated significant responses (Table 7). The results show that, on average, seven in ten respondents $(73.4 \%)$ had a high level of voting culture with $t=20.918(\rho=.000)$, and that they had participated in at least one voting exercise with a mean of $3.672(S D=0.581)$. They believed that elections influence their decision on voting $(81.7 \%)$, and this item also obtained the highest mean $4.085(S D=0.902)$, while the item with the lowest mean is "I frequently vote for student leaders in campus elections" with only six in ten $(65.4 \%)$ respondents participating in student leaders' elections on campus. About seven in ten respondents $(76.7 \%)$ usually watched debates on social media and television, became interested in leadership issues after a voting exercise $(76.7 \%)$, often discussed campus voting with their friends $(74.4 \%)$, paid attention to what is going on in leadership on and off campus (74.3\%), discussed leadership activities with family members (73.8\%), expressed their political opinions through voting (73.6\%), actively campaigned for Copyright $\odot$ GLOBAL ACADEMIC EXCELLENCE (M) SDN BHD - All rights reserved 
their preferred candidates $(72.0 \%)$, frequently monitored the actions of their leaders $(71.0 \%)$, participated in leadership activities on campus (70.8\%), and participated in student debates on campus $(70.8 \%)$. At the same time, they actively engaged in leadership activities off campus $(69.9 \%)$ and frequently voted for student leaders in campus elections $(65.4 \%)$. The results indicate that IIUM students have positive responses towards participating in voting because it might change their way of thinking about politics.

Table 7: One-sample $t$-Test for Voting

\begin{tabular}{|c|c|c|c|c|c|c|c|}
\hline No. & Participation in Voting & $\mathbf{M}^{*}$ & SD & $\%$ & $* *$ & lf & $\rho$ \\
\hline 1 & $\begin{array}{l}\text { Elections influence my decision on } \\
\text { voting. }\end{array}$ & 085 & 0.902 & 81.7 & 21.749 & 326 & .000 \\
\hline 2 & $\begin{array}{l}\text { I usually watch debates on social m } \\
\text { and television. }\end{array}$ & 3.837 & 1.000 & 76.7 & 5.143 & 326 & .000 \\
\hline 3 & 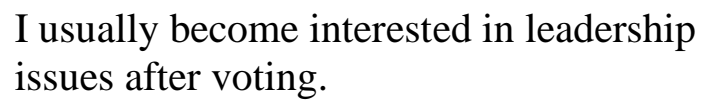 & 3.837 & 1.027 & 76.7 & 42 & 326 & .000 \\
\hline 4 & the & 3.724 & 1.092 & 74.4 & 4 & 326 & .000 \\
\hline 5 & 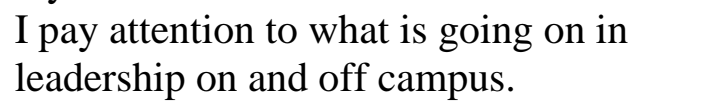 & 3.718 & 0.896 & 74.3 & 14. & 326 & .000 \\
\hline 6 & $\begin{array}{l}\text { I f } \\
\text { wi }\end{array}$ & $36>2+2>0$ & 0.964 & 73.8 & & 326 & .000 \\
\hline 7 & $\begin{array}{l}\text { I ex } \\
\text { voti }\end{array}$ & 3.682 & 1.004 & 73.6 & & 326 & .000 \\
\hline 8 & & & 1.080 & 72.0 & & & .000 \\
\hline 9 & $\begin{array}{l}\text { I fre } \\
\text { elec }\end{array}$ & 3.5 & 0.967 & 71.0 & & 326 & .000 \\
\hline 10 & $\begin{array}{l}\text { I } \\
\text { ca }\end{array}$ & J.J & .189 & 70.8 & & 326 & .000 \\
\hline 11 & $\begin{array}{l}\text { I us } \\
\text { cam }\end{array}$ & 3.544 & 1.040 & 70.8 & & 326 & .000 \\
\hline 12 & $\begin{array}{l}\text { I ac } \\
\text { off }\end{array}$ & 3.495 & 1.101 & 69.9 & & 326 & .000 \\
\hline \multirow[t]{2}{*}{13} & adent leade & 3. & 1.2 & 6 & 4 & 326 & .000 \\
\hline & Overall Voting Participation $(N=327)$ & 3.672 & 0.581 & $\mathbf{7 3 . 4}$ & 20.918 & 326 & .000 \\
\hline
\end{tabular}

* On a 5-point Likert scale where $1=$ never, $2=$ rarely, $3=$ sometimes, $4=$ often, and $5=$ always.

$* *$ Test value is 3

The findings of the study revealed that students' participation in voting exercise influences their voting decisions and that they usually become interested in leadership issues after voting. This concurs with the findings of several scholars (Foreman \& Retallick, 2016; Stephens \& Beatty, 2015) that students' involvement in various political activities across university campuses has a tremendous impact on their leadership skills.

\section{Hypothesis Testing}

\section{Correlation Analysis}

Bivariate correlation analysis was performed to measure the relationships between the variables. The results indicate that all the tested variables yielded statistically significant 


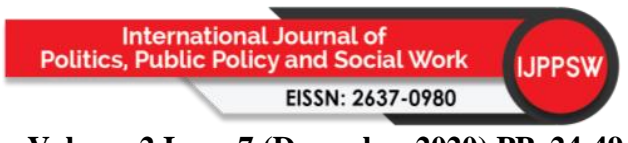

Volume 2 Issue 7 (December 2020) PP. 24-49 DOI: 10.35631/IJPPSW.27003

relationships (Table 8). There was a weak statistically significant relationship between the qualities of student leaders and voting $(r=.207, \rho=.000)$; therefore, H1 is accepted. There was no relationship between important qualities and voting $(r=.003, \rho=.479)$; hence, $\mathrm{H} 2$ is not supported. Additionally, there was a negligible yet significant relationship between the characteristics of student leaders and voting $(r=.116, \rho=.018)$, thereby accepting H3. Similarly, Islamic attributes on leadership and voting was weak but statistically significant ( $r$ $=.325, \rho=.000$ ); hence, $\mathrm{H} 4$ is accepted. Therefore, all hypotheses are supported apart from $\mathrm{H} 2$. This means that the attributes of student leaders significantly affect the voting decision of students, for before they vote for their leaders into office, they ought to scrutinize the leaders to find out what type of qualities and characteristics the leaders possess and that they would steer the students' representative office to a higher place and accord it the respect that leaders deserve.

Table 8: Bivariate Correlations of Qualities, Perception of Important Qualities, Characteristics, and Islamic Attributes of IIUM Student Leaders with Voting

\begin{tabular}{lccccc}
\hline \multicolumn{1}{c}{$\begin{array}{c}\text { Variable }(N= \\
\text { 327) }\end{array}$} & Voting & Qualities & $\begin{array}{c}\text { Important } \\
\text { Qualities }\end{array}$ & Characteristics & $\begin{array}{c}\text { Islamic } \\
\text { Attributes }\end{array}$ \\
\hline $\begin{array}{l}\text { Voting } \\
\text { Qualities }\end{array}$ & $\begin{array}{c}1 \\
r=.207,\end{array}$ & 1 & & & \\
& $\rho=.000$ & & & & \\
Important & $r=.003$, & $r=.540$, & 1 & & \\
qualities & $\rho=.479$ & $\rho=.000$ & & & \\
Characteristics & $r=.116$, & $r=.685$, & $r=.728$, & & \\
& $\rho=.018$ & $\rho=.000$ & $\rho=.000$ & & \\
Islamic & $r=.325$, & $r=.661$, & $r=.361$, & $r=.616$, & \\
attributes & $\rho=.000$ & $\rho=.000$ & $\rho=.000$ & $\rho=.000$ & \\
\hline
\end{tabular}

The results of the study imply that, overall, students want to vote for powerful leaders who are charismatic, visionary, courageous, humble, decision makers, and trustworthy. With these attributes, the students are assured of better and quality services from their leaders whom they have entrusted with power. However, on the characteristic of God-fearing, Al-Ghazali (1994) argues that religion and piety form the foundation upon which leadership is built, and it is regarded as the guardian of everything that does not have a foundation and would therefore collapse if not guided well. Therefore, leaders must have such qualities that instill in them the virtues of fearing Allah while executing their duties.

\section{Discussion and Conclusion}

The respondents of the study consisted of a total of 327 students from different backgrounds, both international and Malaysian students. While there were almost equal numbers of females to males, they came from different levels of study and Kulliyyahs. Overall, the students looked at their student leaders in a positive and motivating way. They viewed them as persistently performing an excellent job and possessing good values through different characteristics, important qualities as well as Islamic leadership principles. Clearly, these experiences have a significant impact on how they view their leaders.

The general relationships between the qualities, characteristics, Islamic attributes of student leaders and voting were weak but statistically significant. All in all, the results of the study show that students tend to consider both inbuilt and external attributes while voting for their 


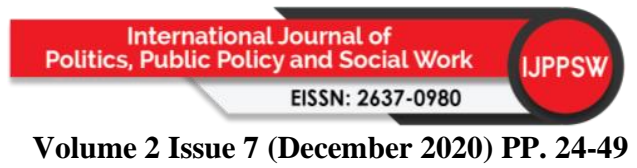

Volume 2 Issue 7 (December 2020) PP. 24-49

DOI: 10.35631/IJPPSW.27003

leaders into power. They also believe that the characteristics and qualities of leadership influence their decision during elections and that the Islamic attributes have a bearing on their decision as to whom they are bringing into power to lead them to the right path. Therefore, the findings of the study support the theory used in the study, that is, the great person theory.

The findings of the study confirm the notion of the great person theory, which is inborn leadership qualities alone are sufficient for leaders to exercise influence over their followers and to become successful at their job. This is in addition to the utility of the great person theory as a framework for understanding leadership attributes and indeed, great leaders are born with their inherent attributes. This is seen after sampling some leadership qualities of IIUM students and the results indicate that the levels of leadership attributes in their leaders are high.

The results of the study have proven that student leaders are likable in general, but they are not easy to work with. This means that the leaders do put much emphasis on their image but forget the relationship that they need to create between them and their followers to have a good working relationship. This finding is congruent with the research done by Shah and Pathak (2015). Additionally, the results reveal that student leaders are competent but lack discipline or moral code because they know that they hold power to themselves.

Leadership is an important part of Islamic society. Islam emphasizes the unity of man in every aspect of life. Every aspect of human life whether social, political, financial, national or international should not be directed by itself without any leader. In this regard, Islam originates the idea of leadership everywhere; even in a journey of three persons, the Prophet (SAW) recommended that one-person functions as the leader. Islam uses various terms for a leader to indicate the area of their authority and eventually discuss the characteristics of leadership, which is mostly influenced by the core teachings of Islam. If society can implement the conditions of Islamic leadership properly, humanity will get a new dimension of prosperity and, hopefully, success everywhere.

\section{Limitations of the Study and Suggestions for Future Research}

The research was conducted during the immediate outbreak of the COVID-19, which made it difficult to select respondents conveniently and hence, the researchers had to select them randomly for the study. The COVID-19 pandemic affected the data collection process because some students had been released from the university to their homes. Hence, the pandemic had affected the timing and method for data collection.

It is suggested that future studies cover various higher learning institutions in order to have a more detailed and clearer picture of how students perceive the attributes of student leaders in different institutions. Since IIUM is predominantly a religious-affiliated institution, future studies should look at other learning institutions that are not religious-based, as they also have student leaders.

Future studies should also focus on other variables because there might be other mediating factors like the nature and needs of the followers, the demands of tasks, and the general socioeconomic environment that were not measured in this study.

Since the study was guided by the great man's theory that suggests that "great leaders are born not made," further research should try to look at other theories to see if they can guide leadership studies well and to get more ideas on how other theories view the subject matter. 
Such theories include the trait theory, behavioral theory, transactional or management theory, transformational theory, visionary leadership theory, and the situational theory.

\section{Biodata}

Faiswal Kasirye is a Ph.D. student at the Department of Communication, IIUM, specializing in Public Relations. He obtained his Bachelor's Degree in Journalism from Islamic University in Uganda, and his master's degree at IIUM. His research interests are in Journalism, Public Relations, Environmental Communication and Social Media. He used to be a journalist with Nation media group, the leading media conglomerate in East Africa.

Saodah Wok is a Professor at the Department of Communication, IIUM. She obtained her Ph.D. from University of Wisconsin-Madison, USA in Mass Communication and specializing in Organizational Communication. Her research interests are Organizational Communication, Social Media, Women Studies, Health Communication, and Family Communication.

\section{References}

Adnan, A. (2006). A study of Islamic leadership theory and practice in K-12 Islamic school in Michigan. Available at: http://contentdm.lib.byu.edu/ETD/image/etd1273.pdf.

Al-Buraey, M. A. (2006). Islamic principles in the management of an organization: A focus on leading, King Fahd University, Al-dharan, available at http://ocw.kfupm.edu.sa/user062/MGT30100102/Islamic\%20Princ\%20Focus\%20on \%20Leadership\%20malaysia2003c1.

Al-Ghazālī. (1994). Ihyā' 'Ulūm al-Dīn, (ed.) Abū Hafs Sayyid ibn Ibrāhīm ibn Sādiq ibn 'Imrān Kaherah: Dār al-Hadīth.

Ali, J. S. (2007). Leadership: An Islamic perspective. In International Conference on Management from Islamic Perspective at Hilton Kuala Lumpur, Malaysia (pp. 1516).

Allen, K., \& Cherry, C. (2000). Systemic leadership: Enriching the meaning of our work (Vol. 7). University Press of America.

Barry, T. J. (2002). Character \& leadership: A sacred trust. Sintok: Universiti Utara Malaysia Press.

Bedford, L. (2012). 8 vital skills to teach your children that will trump an Ivy league education. Retrieved from http://thesurvivalmom.com.

Beyer, P. D. (2010). Authentic leadership in-extremis: A study of combat leadership. Capella University.

Blackwell, C., Cummins, R., Townsend, C. D., \& Cummings, S. (2007). Assessing perceived student leadership skill development in an academic leadership development program. Journal of Leadership Education, 6(1), 39-58.

Charlie, S. (2011). Leadership activities for kids. Retrieved from: http://www.buzzle.com.

Chemers, M. (2014). An integrative theory of leadership. Psychology Press.

Cherry, K. (2012). Leadership theories.

Chobharkar, P. (2011). Leadership skills list. Retrieved from: http://www.buzzle.com.

Cress, C. M., Astin, H. S., Zimmerman-Oster, K., \& Burkhardt, J. C. (2016). Developmental outcomes of college students' involvement in leadership activities. Journal of College student development, 42, 15-27.

Creswell, J. W. (2014). A concise introduction to mixed methods research. SAGE publications.

Drago-Severson, E. (2004). Helping teachers learn: Principal leadership for adult growth and development. Corwin Press.

Copyright $\odot$ GLOBAL ACADEMIC EXCELLENCE (M) SDN BHD - All rights reserved 
Foreman, E. A., \& Retallick, M. S. (2016). The effect of undergraduate extracurricular involvement and leadership activities on community values of the social change model. NACTA Journal, 60(1), 86-92.

Foster-Fishman, P. G., Cantillon, D., Pierce, S. J., \& Van Egeren, L. (2017). Building an active citizenry: The role of neighborhood problems, readiness, and capacity for change. American Journal of Community Psychology, 39(1-2), 91-106.

George, B., Sim, P., Mclean, A., \& Mayer, D. (2007). Managing yourself: Rediscovering your authentic leaders. Harvard Business Review, 85(2), 129-138. Retrieved on March 22, 2020 from www.hbr.org

Godbole, M. (2011). Qualities of leadership in children. Retrieved from http://www.buzzle.com.

Gill, R. (2012). Theory and practice of leadership. Thousand Oaks, CA: Sage.

Hadith Bukhari, no. 316.

Harris, A. (2013). Distributed leadership matters: Potential, practicalities and possibilities. Thousand Oaks CA: Corwin Press.

Harper, S. R., \& Quaye, S. J. (2007). Student organizations as venues for black identity expression and development among African American male student leaders. Journal of College Student Development, 48(2), 127-144.

Hay, I., \& Dempster, N. (2016). Student leadership development through general classroom activities. Educating: Weaving research into practice, 2, 141-150.

Hochwarter, W. A., Witt, L. A., Treadway, D. C., \& Ferris, G. R. (2006). The interaction of social skill and organizational support on job performance. Journal of applied psychology, 91(2), 482-489.

Hoffman, B. J., Woehr, D. J., Maldagen-Youngjohn, R., \& Lyons, B. D. (2011). Great man or great myth? A quantitative review of the relationship between individual differences and leader effectiveness. Journal of occupational and organizational psychology, 84, 347-381.

Holland-Brown, L. (2008). Enhancing student leadership engagement. Retrieved from http://proquest.umi.com/pqdweb?index $=36 \&$ did $=1514988781 \&$ SrchMode $=1 \&$ sid $=1$ $\& \mathrm{Fmt}=2 \&$ VInst $=\mathrm{PROD} \& \mathrm{VType}=\mathrm{PQD} \& \mathrm{RQT}=309 \& \mathrm{VName}=\mathrm{PQD} \& \mathrm{TS}=1231295058$ \&clien $\mathrm{tId}=39685$.

Hoy, A., \& Meisel, W. (2008). Civic engagement at the center: Building democracy through integrated cocurricular and curricular experiences. Association of American Colleges and Universities.

Irvin, L. E., \& White, D. (2004). Keys to Effective Leadership. Principal Leadership, 4(6), 20-24.

Ismail, Y. (2007). A proposed approach to the development of Islamic management as a discipline. In International Conference on Management from Islamic Perspective, Hilton Kuala Lumpur, Malaysia (pp. 15-16).

Kazmi, A., \& Ahmad, K. (2007, May). Managing from Islamic perspectives: Some preliminary findings from Malaysian Muslim-managed organizations. In International conference on management from Islamic perspective, Hilton Kuala Lumpur, Malaysia (pp. 15-16).

Khan, A. (2007). Islamic leadership: A success model for everyone and all times.

Khan, M. W. (1998). Prophetic principles of success. Minaret, September, 8-9, available at: http://makkah.wordpress.com/leadership-and Islam.

Keller, M. (2012). 5 teachability principles that could change your leadership forever. Retrieved from http://mattkelleronline.com. 
Kessie, J. Z. (2012). Leadership qualities: Teaching kids to be leaders. Retrieved from http://jaredzanekessie.hubpages.com.

Khaliq, A. (2009). Leadership and work motivation from the cross-cultural perspective. International Journal of Commerce \& Management, 29(1), 72-84, available at: Emerald database.

Khaliq, A. (2007). Management from Islamic Perspectives - Principles and practices, Research Centre, IIUM, Kuala Lumpur.

Khan, A. (2007). Islamic leadership: A success model for everyone and all times. Available at: http://americanchronicle.com/articles/view/33073 (Retrieved March 2020).

Komives, S. R., Dugan, J., Owen, J. E., Slack, C., \& Wagner, W. (2011). Handbook for student leadership development (2nd Ed.). A publication of the national clearinghouse for leadership programs. San Francisco, CA: Jossey-Bass.

Larson, R. W., Wilson, S., \& Mortimer, J. T. (2012). Conclusions: Adolescents \& apes; Preparation for the future. Journal of Research on Adolescence, 12, 159-166. https://doi.org/10.1111/1532-7795.00029.

Layfield, K. D., Radhakrishna, R. B., \& Andreasen, R. J. (2000). Self-perceived leadership skills of students in leadership programs in agriculture courses. The Journal of Southern agricultural education research, 50(1) 62-68.

Lo, M. C., Ramayah, T., De Run, E. C., \& Ling, V. M. (2009). New leadership, leadermember exchange and commitment to change: The case of higher education in Malaysia. World Academy of Science, Engineering and Technology, 41, 574-580.

Lizzio, A., \& Wilson, K. (2009). Student participation in university governance: The role conceptions and sense of efficacy of student representatives on departmental commits. $\begin{array}{llll}\text { Studies in Higher } & \text { Education, } & 34(1), & 69\end{array}$ 84.https://doi.org/10.1080/03075070802602000.

Lukman, T. (1995). The Islamic Polity and Leadership. Klang: Baron Production Sdn Bhd.

Manning, G., \& Curtis, K. (2017). The art of leadership (2nd Ed.). Boston: McGraw-Hill.

Morris, J. T. (2010). The impact of authentic leadership and ethical organizational culture on auditor behavior. (Doctoral dissertation). Retrieved March 21, 2020, from www.sandiego.edu/.../leadership.../dissertation_directory.php.

Moore, J. (2010). Teaching your child conflict resolution. Retrieved from http://voices.yahoo.com.

Nair, T. (2011). Teaching leadership skills to students. Retrieved from http://www.buzzle.com

National FFA Organization. (2009). A library of activities for inside and outside the classroom. Retrieved from https://www.ffa.org.

Owen, J. E. (2012). Findings from the multi-institutional study of leadership institutional survey: A national report. college park, MD: National clearinghouse for leadership programs.

Pearce, C. L., \& Conger, J. A. (Eds.) (2003). Shared Leadership: Reframing the hows and whys of leadership, Sage, Thousand Oaks, CA.

Pierce, J. L., \& Newstrom, J. W. (2006). Leaders \& the leadership process: Readings, selfassessments, \& applications (4th Ed.). Boston: McGraw-Hill.

Pierro, A., Raven, B. H., Amato, C., \& Belanger, J. J. (2013). Bases of social power, leadership styles, and organizational commitment. International Journal of Psychology, 48(6), 11221134.

Rafiki, A. (2020). Islamic leadership: Comparisons and qualities. In digital leadership-A new leadership style for the 21st Century. IntechOpen. 


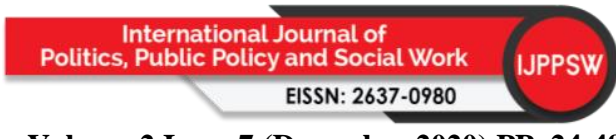

Volume 2 Issue 7 (December 2020) PP. 24-49 DOI: 10.35631/IJPPSW.27003

Roux, S. (2010). The relationship between authentic leadership, optimism, self-efficacy and work engagement: An exploratory study (Doctoral dissertation, Stellenbosch: University of Stellenbosch).

Saunders, M., Lewis, P., \& Thornhill, A. (2007). Research methods for business. London: Pitman, 124-126.

Segal, J., \& Smith, M. (2013). Conflict resolution skills: Building the skills that can turn conflicts into opportunities. Helpguide. org (Retrieved March 2020).

Selamat, N., Nordin, N., \& Adnan, A. A. (2013). Rekindle teacher's organizational commitment: the effect of transformational leadership behavior. Procedia-Social and Behavioral Sciences, 90, 566-574.

Shah, S., \& Pathak, K. (2015). Exploring Important Leadership qualities and characteristics among adolescent students. IOSR Journal of Humanities and Social Science (IOSRJHSS), 20(9), 46-52.

Shakir, R. (2009). Soft skills at the Malaysian institutes of higher learning. Asia Pacific Education Review, 10(3), 309-315.

Shertzer, J., Wall, V., Frandsen, A., Guo, Y., Whalen, D. F., Shelley, I. I., \& Mack, C. (2015). Four dimensions of student leadership: What predicts students' attitudes toward leadership developrnent? College Student Affairs Journal, 25(1), 85-108.

Segal, J., \& Smith, M. (2013). Conflict resolution skills: Building the skills that can turn conflicts into opportunities. Retrieved from http://www.helpguide.org.

Shinde, G. (2010). Leadership activities for elementary students. Retrieved from http://www.livebinders.com

Stephens, C. M., \& Beatty, C. C. (2015). Leading and thriving: How leadership education can improve first-year student success. Journal of leadership education, 14(3), 119-131. https://doi.org/10.12806/V14/I3/T1.

Skalicky, J., Pedersen, K. W., van der Meer, J., Fuglsang, S., Dawson, P., \& Stewart, S. (2018). A framework for developing and supporting student leadership in higher education. Studies in Higher Education, 45,1-17. https://doi.org/10.1080/03075079.2018.1522624.

Swan, K. (2011). Raising tomorrow's leaders: 6 skills to teach your children. Retrieved from http://www.asuccessfulwoman.com.

Tai, M. K., Kareem, O. A., Nordin, M. S., Khuan, W. B. (2018). Principal change leadership competencies and teacher attitudes toward change: the mediating effects of teacher change beliefs. International Journal of Leadership in Education, 21(4), 427-446.

Tan, B., Pan, S. L., \& Zuo, M. (2015). Harnessing collective IT resources for sustainability: Insights from the green leadership strategy of China mobile. Journal of the Association for Information Science and Technology, 66(4), 818-838.

Tan, M. H., \& Adams, D. (2018). Malaysian student leaders' perception of their leadership styles. International Journal of Innovation and Learning, 23(3), 368-382.

Tardanico, S. (2013). 10 traits of courageous leaders. Retrieved from http://www.forbes.com.

Tardanico, S. (2013). 10 traits of courageous leaders. Retrieved from http://www.forbes.com

Terrell, M. C., \& Cuyjet, M. J. (1994). Developing student government leadership (No. 66). San Francisco, LA: Jossey-Bass Inc. Pub.

Tracy, B. (2012). The seven leadership qualities of great leaders. Retrieved from http://www.briantracy.com.

Trautman, K. (2017). Leadership for today managing conflict within groups. Retrieved from http://pubstorage.sdstate.edu. 
Volume 2 Issue 7 (December 2020) PP. 24-49 DOI: 10.35631/IJPPSW.27003

Voon, M. L., Lo, M. C., Ngui, S. K., \& Peter, S. (2009). Leadership styles in context of institution of higher education in Malaysia. Retrieved from bai2009. org/file/Papers/1657. doc.

Voyer, P. (2011). Courage in leadership: From the battlefield to the boardroom. Retrieved from http://iveybusinessjournal.com

Walumbwa, F. O., Avolio, B. J., Gardner, W. L., Wernsing, T. S., \& Peterson, S. J. (2008). Authentic leadership: Development and validation of a theory-based measure. Journal of Management, 34(1), 89-126.

Warren, R. (2013). You cannot grow without humble, teachable attitude. Retrieved from http://purposedriven.com.

Weir, D. (2014). Using student voice to develop student leadership in an inner city school (Doctoral Thesis, University of Nottingham).

Williams, H., \& Johnson, T. (2013). Strategic leadership in schools. Education, 133(3), 350355.

Owings, W. (2003). Best practices, best thinking, and emerging issues in school leadership. USA: Corwin Press.

Wok, S., \& Hashim, J. (2014). Communication networks, organisational contacts and communication power in grooming professionals for career success. Malaysian Journal of Communication, 30, 219-242. Retrieved from http://www.ukm.my/jkom/journal/volumes/volume30-S-2014.html.

Yang, C. (2014). Does ethical leadership lead to happy workers? A study on the impact of ethical leadership, subjective well-being, and life happiness in the Chinese culture. Journal of Business Ethics, 123, 513-525.

Yukl, G. (1999). An evaluation of conceptual weaknesses in transformational and charismatic leadership theories. The Leadership Quarterly, 10(2), 285-305. 